\title{
$0^{\& T}$
}

\section{Teachers' Decision-Making Process When Designing ESP Materials in the Languages Without Borders Program}

\section{O processo de tomada de decisão de professores ao elaborar materiais de IPE no Programa Idiomas sem Fronteiras}

\author{
Gabriela Salvador VIEIRA* \\ Cláudia Jotto KAWACHI-FURLAN ${ }^{* *}$
}

ABSTRACT: The objective of this study is to explore teachers' decision-making processes and the factors that influence their decisions when designing English for Specific Purposes (ESP) materials. We seek to analyze not only the decisions made by language teachers when designing materials, but also the reasons that support such decisions. This research focuses on teachers' perspectives regarding foreign language education and material design, and the motivations for their pedagogical choices. In this sense, this work may contribute to fill the gap in the literature pointed out by Tomlinson (2012) about the need for studies that investigate material development. The methodology of this study is qualitative and interpretative. Participants are teachers who work in the Languages without Program (LwB) at UFES. Data was collected through interviews with teachers who are also material developers. Based on the results of this study, we highlight the challenges involved in designing materials for teachers who are in an undergraduate course, and the implications of the findings for implementing appropriate ESP materials in the program LwB at UFES. The findings also help us reflect on the effectiveness of the program's policy of teacher education in the context of ESP.

KEYWORDS: Languages without Borders 1. Material Design 2. Teacher Educadion 3. English for Specific Purposes 4.
RESUMO: O objetivo deste estudo é explorar os processos de tomada de decisão de professores e os fatores que influenciam suas decisões ao elaborar materiais didáticos de Inglês para Propósitos Específicos (IPE). Buscamos analisar não apenas as decisões tomadas pelos professores de línguas ao elaborar materiais, mas também os motivos que sustentam tais decisões. Esta pesquisa centra-se nas perspectivas dos professores sobre ensino de línguas estrangeiras e elaboração de materiais, e nas motivações para suas escolhas pedagógicas. Nesse sentido, este trabalho pode contribuir para preencher a lacuna na literatura apontada por Tomlinson (2012) sobre a necessidade de estudos que investigam o desenvolvimento de materiais. A metodologia deste estudo é qualitativa e interpretativa. Os participantes são professores que trabalham no programa Idiomas sem Fronteiras (IsF) na UFES. Os dados foram coletados através de entrevistas com professores que também desenvolvem material. Com base nos resultados deste estudo, destacamos os desafios envolvidos na elaboração de materiais para professores que estão em um curso de graduação, e as implicações dos resultados para a implementação de materiais de IPE adequados no programa IsF da UFES. Os resultados também nos ajudam a refletir sobre a eficácia da política de formação de professores no contexto de IPE.

PALAVRAS-CHAVE: Idiomas sem Fronteiras 1. Material didático 2. Formação de professores 3. Inglês para Propósitos Específicos 4.

\footnotetext{
* Graduada em Letras - Inglês pela Universidade Federal do Espírito Santo (UFES).

** Doutora em Linguística pela Universidade Federal de São Carlos (UFSCar). Professora no Departamento de Línguas e Letras e no Programa de Pós-Graduação em Linguística da Universidade Federal do Espírito Santo (UFES).
} 


\section{Introduction}

The Languages without Borders (LwB) Program is part of the government's policy for the internationalization of Brazilian universities. One of the main goals of the program is teacher education, as it offers teaching residency to foreign language teachers in initial and continuous education in order to train professionals for

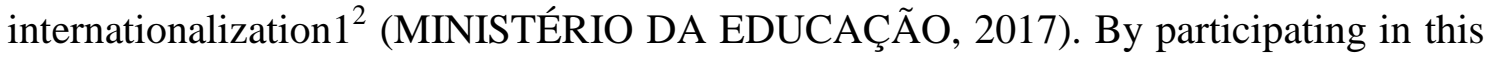
program, teachers become familiarized with the teaching of English for Specific Purposes (ESP), since one of the focuses of the program is to meet the specific needs and demands of the academic community. This paper focuses on the specific context of English teachers of this program at the Federal University of Espírito Santo (UFES).

The English without Borders (EwB) team at UFES decided to locally produce their own materials for courses, as a global book would fail to address the specific needs and demands of the local community. EwB teachers with pedagogical supervision of the coordinator developed the syllabus and specific content for the courses offered. In addition, they were responsible for designing materials that fit students' needs and interests.

Tomlinson remarks that "it is inevitable that coursebooks communicate a view of teaching and learning, a view of the target language and the culture(s) they represent and the worldview of their producer" (2012, p.165). As material design might represent teachers' perspective on teaching and learning languages, it is relevant to investigate this process. Therefore, we believe this paper may contribute to understanding the perspectives of student-teachers regarding foreign language education and the motivations for their pedagogical choices.

The objective of this study is to explore ESP teachers' decision-making processes and the factors that influence their decisions when designing materials. This paper results from an undergraduate research, the original paper contains four categories, which were established in order to organize the data collected: formulating goals and objectives; finding input materials; creating activities; general questions. Due

\footnotetext{
${ }^{2}$ According to Knight, "internationalization at the national, sector, and institutional levels is defined as the process of integrating an international, intercultural, or global dimension into the purpose, functions or delivery of postsecondary education.” $(2015, \mathrm{p} .2)$
} 
to space limitations, we are going to focus on "formulating goals and objectives", which reflects what teachers consider when they are preparing ESP materials.

It is our understanding that by planning and designing teaching material, teachers reflect about their views of language, teaching, and learning. Thus, this process of material development is completely related to teacher education since "the process of educating is a process of preparing people to make choices", as defended by LarsenFreeman (1983, p. 266).

Augusto-Navarro and Gattolin point out that "one of the biggest gains in designing their own materials in a project like $\mathrm{LwB}$, or in university extension programs in general, is teacher education" (2016, p. 258, our translation). Some of the skills that teachers practice while developing materials, such as: "exercising patience, developing research skills for 'raw material', reflecting on necessary adaptations, considering different groups of learners, and learning how to work as a team" (AUGUSTONAVARRO; GATTOLIN, 2016, p. 261, our translation) are relevant activities in teacher education programs that help student-teachers make informed decisions.

\section{Material design and English for Specific Purposes}

English for Specific Purposes, such as other forms of language teaching, is primarily concerned with language learning. However, it differs from the others, since "ESP has paid scant attention to the question of how people learn, focusing instead on the question of what people learn." (HUTCHINSON; WATERS, 1987, p. 2). ESP is considered a learning-centered approach. In addition to that, we consider it to be a learner-centered approach.

With the rise of ESP, the focus was now on the learners and their attitudes toward learning. Thus, courses in which learners' needs and interests were considered paramount started to be developed.

In some Brazilian universities, the program Languages without Borders is the one that brings ESP to the fore. With the implementation of the program, the demand for ESP courses in a national level in the universities was verified (DELLA-ROSA et.al., 2016). The relevance of ESP makes sense in the academic context, since the 
courses are able to take into consideration the registers of students' specific areas of study, as well as the real communicative situations in which they would need to interact in their context. In the context of ESP, materials must be designed in order to suit learners' interests and needs. Material developers' decisions must be guided taking into consideration this fundamental basis of ESP, if they find themselves in this context.

Designing materials is no easy task for a teacher; however, we argue that it is necessary, especially when the purpose is to meet the demands of a specific community. As mentioned by Tomlinson, "most global coursebooks these days seem to be clones of other commercially successful coursebooks". (2010, p. 97). And these coursebooks, driven by the need to sell, end up standardizing teaching and providing general teaching materials.

However, we take the same stance as Tomlinson in this study, which is that "language-learning materials should ideally be driven by learning and teaching principles rather than be developed ad hoc or in imitation of best-selling coursebooks" (TOMLINSON, 2010, p. 81). The author affirms that these principles are composed of: theories of language acquisition and development; principles of teaching; our current knowledge of how the target language is actually used; the results of systematic observation and evaluation of materials in use.

In the context of ESP, which is the context of the program LwB, it is important to locally design materials. There are some reasons to support our claim, which are mentioned by Hutchinson and Waters (1987). For example, teachers who design their own materials provide coursebooks that fit the specific subject area of learners. Furthermore, since publishers will hardly produce materials for such limited markets, coursebooks that attend the wide range of course types created by ESP programs such as LwB may not be available commercially. In addition to that, the authors highlight some difficulties regarding price and commercializing imported material. These reasons represent a reality for the LwB program at UFES.

As mentioned by Hutchinson and Waters, "for these and other reasons, there is already an established tradition of ESP teachers producing in-house materials" (1987, p. 106). We agree when the authors mention that this process of material development helps teachers become aware of what is involved in teaching and learning. This is one of 
the main goals of the LwB program: teacher education. However, on top of that, we claim that it is important that these teachers be aware and use their knowledge of language learning and teaching principles in order to make informed decisions when elaborating materials.

\section{The EwB Program at UFES and Participants' Profile}

As Mozer and Kawachi-Furlan (2017) mention, the program English without Borders at UFES started in 2013, but at first it had the sole purpose of offering the TOEFL exam for free for the academic community. In 2014, the program began to offer face-to-face English classes for students, professors and civil servants at UFES. In order to enroll in the EwB courses at UFES today candidates must take a proficiency test, either the TOEFL ITP or the proficiency exam offered by My English Online (MEO). Once they receive their grades in one of the tests mentioned above, they are able to enroll in the courses in the EwB program's website. Students who have not taken the TOEFL test but have used the proficiency exam offered by My English Online in order to enroll have to be active in the MEO course in order to take the face-to-face EwB classes. Most candidates at UFES who have taken the proficiency exams are A2 and $\mathrm{B} 1^{3}$ according to the Common European Framework of Reference, so that is the target audience for which EwB courses are created.

The focus of ESP courses is to meet students' needs, therefore the EwB team at UFES decided to locally produce their own materials for courses, since a global book would fail to address the specific needs and demands of the community and the target audience. EwB teachers with pedagogical supervision of the coordinator come up with syllabus and specific content for the courses and materials which will fit students' needs and interests, this enables them to design materials which take into consideration the reality and specificities of UFES community.

The EwB team chooses the courses that will be offered at UFES from a list of course titles presented by the managing board of the EwB program centered in Brasília.

\footnotetext{
${ }^{3}$ According to the Common European Framework of Reference, students in the A2 level are described as having "an ability to deal with simple, straightforward information and begin to express oneself in familiar contexts" (EXAM ENGLISH, 2014), teachers often describe it as "basic" or "pre-intermediate" level. Students in the B1 level are described as having "the ability to express oneself in a limited way in familiar situations and to deal in a general way with nonroutine information" (EXAM ENGLISH, 2014), teachers often describe it as "intermediate" level.
}

Olhares \& Trilhas | Uberlândia | vol.21, n. 2 | maio/agosto/2019 - ISSN 1983-3857 
The course menus were created in a collaboration among English without Borders staff members (teachers and coordinators) from different states of Brazil in order to have one official list of courses that can be offered all over the country. But each EwB language centers (known as NucLis) decides the courses they will offer and can design their own materials for those courses based on the needs and reality of students of that university. In 2017, teachers at NucLi UFES decided to develop the following materials: Written Comprehension: strategies, Oral comprehension: strategies, Varieties of the English Language, and Intercultural Communication.

When designing new materials, the EwB teachers at UFES generally organize themselves in committees. Each committee is responsible for producing and revising one material for one course. Teachers usually choose the committee they will be a part of based on the subjects and courses they identify themselves the most with. Everything is done with the supervision of the pedagogical coordinator. The committee will decide within themselves the specific content, themes, pattern of activities, layout and other parts of the materials; considering the objectives and syllabus of that course. Teachers must always be aware of copyright issues when searching for input materials and other activities, for this reason, the coursebooks require a lot of thought and original ideas from teachers.

We chose the material Varieties of the English Language as a basis for the interview questions because it was the most recent one to be developed by teachers, and also because the author of this paper had not been involved in developing this specific material, as a teacher in the program. The objectives of this course according to the syllabus are that by the end of the course, students should be able to: 1- understand the role of linguistic variations in the English Language; 2- recognize the diversity in the practical language forms in different countries where English is spoken; 3- understand some varieties present in texts that circulate in different regions and countries where English is spoken; 4- critically understand issues related to accent and intelligible pronunciation.

Based on the qualitative methodology, we analyzed the material Varieties of the English Language in order to select the main topics we wanted to discuss with participants. After this analysis, we discussed the aspects that influenced teachers' 
decisions when formulating goals and objectives. Data was collected through interviews with participants.

Out of the seven teachers who participated in the program English without Borders at UFES (when data was collected), three of them were chosen to be participants of this study because together they designed the material Varieties of the English Language. The profiles of the participants are presented in the following table. It is important to point out that we used fictitious names for the purpose of this work.

Table 1: Participants' profile

\begin{tabular}{|c|c|c|c|}
\hline Participant & $\begin{array}{c}\text { Educational } \\
\text { background }\end{array}$ & $\begin{array}{c}\text { How long they have } \\
\text { been working at EwB }\end{array}$ & $\begin{array}{c}\text { Experience with material } \\
\text { design }\end{array}$ \\
\hline Isabela & $\begin{array}{c}\text { She has a degree in } \\
\text { Letras Inglês from } \\
\text { UFES. }\end{array}$ & $\begin{array}{c}\text { She has been working at } \\
\text { EwB for three years. }\end{array}$ & $\begin{array}{c}\text { She has participated in the } \\
\text { designing of four materials. She } \\
\text { has adapted two materials. She } \\
\text { has also helped in compiling } \\
\text { materials for other courses. }\end{array}$ \\
\hline Raquel & $\begin{array}{c}\text { She has a degree in } \\
\text { Business Law. She } \\
\text { is in the seventh } \\
\text { term of Letras } \\
\text { Inglês at UFES. }\end{array}$ & $\begin{array}{c}\text { She has been working at } \\
\text { EwB for two years. }\end{array}$ & $\begin{array}{c}\text { She has participated in the } \\
\text { designing of two materials. She } \\
\text { has also prepared and adapted } \\
\text { handouts for other courses. }\end{array}$ \\
\hline William & $\begin{array}{c}\text { He is in the fourth } \\
\text { term of Letras } \\
\text { Inglês at UFES. }\end{array}$ & $\begin{array}{c}\text { He has been working at } \\
\text { EwB for one year and } \\
\text { two months. }\end{array}$ & $\begin{array}{c}\text { anguage is the first material he } \\
\text { has helped design. He has } \\
\text { prepared handouts for classes } \\
\text { before he started working at } \\
\text { EwB. }\end{array}$ \\
\hline
\end{tabular}

Source: Author's data.

In this table, we provide a summary of participants' academic and professional background. Based on the data presented, it is possible to observe participants are in different moments of their undergraduate courses, as well as the period of time working at EwB, ranging from 1 to 3 years at the program. Their experience with material development is also diverse. We consider this heterogeneity is extremely valuable to the team, as teachers were able to learn with one another. In addition, we believe this information is important for us to understand which aspects of their lives influence their answers and perspectives. 
In the next item, we analyze participants' points of view regarding material design, more specifically how they plan the teaching-learning goals of their coursebooks.

\section{How participants focus on the goals of the materials they develop}

In this item, we analyze how participants focus on developing the goals and objectives of their units, lessons and the material as a whole. The idea was to have access to their reflections about what they considered before they started to actually build the material; when they were discussing with their coworkers about what to do, and also when they were brainstorming by themselves (without the help of their coworkers). This section is concerned mainly with the planning of the material, before they started to design it.

When questioned ${ }^{4}$ about what they took into consideration when planning this material, and what their main concern was, participants answered:

\begin{tabular}{|l|l|}
\hline Isabela & $\begin{array}{l}\text { So, the idea of the material for the course varieties of the English language was to } \\
\text { focus on English as we speak, English as we see, English as we use around the } \\
\text { world. Not just in Brazil, not just the American English, not just the British English. } \\
\text { [...] The idea was to make students aware of how English has transformed itself, and } \\
\text { this transformation has happened because of the people, because of the people using } \\
\text { English... [...] What was the power of English, how it became this thing that we see } \\
\text { today. }\end{array}$ \\
\hline Raquel & $\begin{array}{l}\text { So what I thought is that we should introduce the phonetic alphabet to the students } \\
\text { and focus on the sounds that are most important for them as Brazilian students or as } \\
\text { Portuguese speakers, right? Yeah, and then we focused on some specific sounds that } \\
\text { might be harder for Brazilians, or that might be more interesting for them to know } \\
\text { about. }\end{array}$ \\
\hline William & $\begin{array}{l}\text { I was concerned with the level; it was supposed to be aimed at B1 students so we } \\
\text { couldn't bring anything too easy or not enough challenging to students. The second } \\
\text { thing was the appropriateness of the content because this course has a very broad } \\
\text { yet specific content which is varieties of English [...]. }\end{array}$ \\
\hline
\end{tabular}

Based on their answers, we can observe that four items are mainly considered when planning: level, content, student's interests/needs, and the syllabus.

In Isabela's answer we can notice that she already had a very specific idea in her mind, it was very clear to her what the material and the unit she developed were supposed to be about and what it should contain. This definition that she presented was

\footnotetext{
${ }^{4}$ What did you take into consideration when planning this material? (question from the interview)

Olhares \& Trilhas | Uberlândia | vol.21, n. 2 | maio/agosto/2019 - ISSN 1983-3857 
completely in sync with the syllabus and the objectives of the course, although she did not mention this specifically. It seems she was also worried about the content, what students should know by the end of the course.

Raquel was more concerned with students' needs and interests. She was worried about what was important for them to know as Brazilians and also what would interest them as individuals. Although she did not mention this specifically as well, we can infer that this idea comes from the definition of ESP, which characterizes the context of the program EwB. This idea of catering to students' needs and interests is also mentioned by Tomlinson (2010), which has been used by the EwB teachers at NucLi UFES as a theoretical background for designing materials.

William mentioned two different concerns: level and content. When mentioning his concern with the language level in the material, he stated that he wanted it to be challenging for students. He was also concerned with the content being appropriate in regards to the objectives of the course. In his full answer, he also talked very briefly about what students may or may not be interested in, and about his concern with the length of the material, since it was supposed to be a 32-hour course.

We noticed that all teachers mentioned the types of concerns that are important in the area of teaching materials: content, language level, student's interest/needs, purpose of the course and syllabus. Although some of them did not state these words specifically, by interpreting the data, we can infer some of their answers.

Tomlinson (2010) discusses the importance of some of these aspects in his Principles of effective materials development. For instance, in one of his principles he points out the importance of teachers being able to "personalize and localize the materials and to relate them in different ways to the needs, wants, and learning-style preferences of individual learners." (p.96-97). According to the author, students' needs and interests need to be considered in order to help learners acquire language in this process.

Being attentive to the language level of the material so that it matches the level of proficiency of the students is a basic concern that a material developer must have. As Tomlinson (2010) affirms, one prerequisite for language acquisition is that learners be exposed to comprehensible input of language in use. However, the participant William 
mentioned that he was not only worried about that, but also that the language input be challenging to students. This is also a significant concern, as hinted by Tomlinson (2010), instead of providing explicit information about the use of a particular feature "it is much more powerful to help the learners (preferably in collaboration) to make discoveries for themselves" (p. 93).

The concern with the content being appropriate to the objectives and syllabus of the course is also relevant. One of the principles of language teaching and materials development presented by Tomlinson is that "the content and methodology of the teaching should be consistent with the objectives of the course" (2010, p. 95).

When the teachers were asked if their decisions were informed by any research supported principle, theory or methodology; they said:

\begin{tabular}{|l|l|}
\hline Isabela & $\begin{array}{l}\text { We use the communicative approach, and we also use the English for Specific } \\
\text { Purposes approach. }\end{array}$ \\
\hline Raquel & $\begin{array}{l}\text { Not exactly, since I had already taught the pronunciation course, I based myself on } \\
\text { the book that we used. [...] I based on it and what worked when I taught the class, } \\
\text { but not like a specific theory or methodology. }\end{array}$ \\
\hline William & $\begin{array}{l}\text { Before we started creating this material specifically we had read Tomlinson's } \\
\text { principles of coursebooks and materials for this specific purpose, and I remember } \\
\text { drawing some concepts from it to work better on this project. }\end{array}$ \\
\hline
\end{tabular}

In their answers we could notice that their decisions were informed either by theory, experience or course approach. Isabela did not mention any theory or text she had read, but she mentioned two specific approaches: the communicative approach and ESP. Both of these are a part of the Languages without Borders program, which we imagine is the reason for her mentioning both, especially since she used the pronoun "we", which can mean the teachers from the program.

According to Hutchinson and Waters, ESP courses are designed to meet students' needs and interests. "The assumption underlying this approach was that the clear relevance of the English course to their needs would improve the learners' motivation and thereby make learning better and faster." (HUTCHINSON; WATERS, 1987 p. 8). It is a learner-centered approach as well as a learning-centered approach. All of the decisions taken in an ESP course are based on the reasons why people learn a language. 
Raquel shows influence of her previous experience as an English teacher. If it has worked before, she thinks she can continue working with this. She is heavily influenced by her experience, which we interpreted as the reason for her not being able to name one text, theory, approach or methodology. According to Tomlinson, many publications that discuss how authors typically write English Language Teaching materials reveal that "many experienced authors rely on their intuitions about what 'works' and make frequent use of activities in their repertoire that seem to fit with their objectives. Very few authors are actually guided by learning principles [...]" (2010, p. $81-82)$.

Tomlinson states that most global coursebooks and many local materials "are not driven or informed by principles of language acquisition and development. Some of them manage to help learners to acquire language because their writers have been effective teachers and are intuitively applying principles of teaching” (2010, p. 99). The author argues that most global materials would be more effective if they were guided by principles of language teaching and learning, and not only relied on teachers' previous experiences.

As for William, his decisions might have been informed by theory. He mentioned this specific text about material development written by Tomlinson (2010), which they had discussed in an English without Borders meeting. He said that he took this text into consideration when planning this material, which later he mentioned it was the first one he had ever designed.

Thus, we can notice that two participants tend to follow the author's proposal. Isabela seems to have her decisions supported by the principles of language teaching and learning proposed by the Communicative Approach and also the concepts of ESP. William was guided the Principles of effective materials development (2010) presented by Tomlinson himself. Whereas Raquel is more influenced by her previous experience. However, it is possible that her experience was also based on theoretical principles, since we know that these concepts have been presented, read and discussed in EwB meetings with the whole group of teachers. But it is not possible to confirm that only based on her answer. 


\section{Conclusion}

The main focus of this study was to reflect about teachers' decision-making process when planning ESP teaching material at the English without Borders Program at UFES. In order to understand what participants took into consideration when designing local coursebooks, we interviewed three EwB teachers focusing on their experience with the material used in the course Varieties of the English Language. Based on the analysis of their answers, it was possible to observe the influence of theoretical principles and previous teaching experience in participants' decisions.

Considering the importance of making informed choices, we highlight the role of the Languages without Borders Program as a possibility of helping teachers to become aware of their decisions. The focus of teacher development sessions at UFES is to raise teachers' awareness of the implications of material design and teacher's choices. We argue that the $\mathrm{LwB}$ program is a remarkable opportunity of discussion and preparation of student-teachers to design their own materials, to think about curriculum, syllabus and course development, and also to make informed choices.

There is no easy answer or recipe to educate someone on which decisions to make in order to be successful at teaching, especially considering the many possible pedagogical contexts that exist. In addition, it is impossible (and not even desirable) to prepare teachers for every situation they may encounter in their careers. Therefore, as stated by Larsen-Freeman (1983), making informed choices is what teaching consists of.

\section{References}

AUGUSTO-NAVARRO, E. H.; GATTOLIN, S. R. B. Desenvolvimento de materiais didáticos para o programa IsF: Consideração de necessidades prementes, do contexto e da formação de professores. In: SARMENTO, S.; ABREU-E-LIMA, D. M.; FILHO, W. B. M. Do Inglês sem Fronteiras ao Idiomas sem Fronteiras: A construção de uma política linguística para a internacionalização. Belo Horizonte: Ufmg, 2016. p. 249-271.

DELLA-ROSA, S.; KAWACHI-FURLAN, C.; AUGUSTO-NAVARRO, E. H. Inglês para Propósitos Específicos (IPE): características e tendências atuais de ensino. Revista EntreLínguas, Araraquara, v. 2, n. 1, p.25-39, jan./jun. 2016.

EXAM English. CFE Levels. Disponível em:

<https://www.examenglish.com/CEFR/cefr.php> Acesso em: 11 de dezembro de 2017. 
HUTCHINSON, T; WATERS, A. English for Specific Purposes: a learning centred approach. New York: Cambridge University Press, 1987.

KNIGHT, J. Updating the Definition of Internationalization. International Higher Education, n. 33, p. 2-3, 2015.

LARSEN-FREEMAN, D. Training Teachers or Educating a Teacher. In: JAMES, E., STERN, H. H.; STREVENS, P. (eds.) Georgetown University Round Table on Languages and Linguistics. Washington, D.C.: Georgetown University Press, p. 264 $274,1983$.

MINISTÉRIO DA EDUCAÇÃO. Texto de apresentação do programa. Página oficial do Idiomas sem Fronteiras, 2017. Disponível em <http://isf.mec.gov.br/programaisf/entenda-o-isf>. Acesso em 11 Dez. 2017.

MOZER, I.; KAWACHI-FURLAN, C.J. Not by the book: the experience of designing teaching material for an English for Specific Purposes course in the Program Languages without Borders. Revista Digital dos Programas de Pós-Graduação do Departamento de Letras e Artes da UEFS. Feira de Santana, v. 18, n. Especial, p. 145-162, outubro-dezembro/2017

(DOI: http://dx.doi.org/10.13102/cl.v18iEspecial.2032)

TOMLINSON, B. Principles of effective materials development. In: HARWOOD,

Nigel. English language teaching materials: theory and practice. New York:

Cambridge University Press, 2010, p. 81 - 108.

TOMLINSON, B. Materials development for language learning and teaching. Language Teaching. Cambridge University Press, 2012, p. 143-179. 